\title{
Microbial Metabolism of Amino Alcohols. Control of Formation and Stability of Partially Purified Ethanolamine Ammonia-lyase in Escherichia coli
}

\author{
By CAROL M. BLACKWELL, F. ANNE SCARLETT \\ AND JOHN M. TURNER \\ Department of Biochemistry, University of Liverpool, P.O. Box I47, \\ Liverpool L69 $3 B X$
}

(Received 6 July 1976)

SUMMARY

Induction of ethanolamine ammonia-lyase formation in Escherichia coli required both ethanolamine and vitamin $\mathrm{B}_{12}$, and was gratuitous during growth on glycerol. Ethanolamine analogues inhibited enzyme activity and inhibited growth with ethanolamine as the nitrogen source, but did not act as inducers. Enzyme formation was more rapid when ethanolamine was added to cultures containing vitamin $\mathbf{B}_{12}$ rather than the reverse. Enzyme formation was subject to catabolite repression, glucose and acetate being particularly effective. Chloramphenicol, I-aminopropan2-ol and I,3-diaminopropan-2-ol prevented enzyme induction. Ethanolamine ammonia-lyase, resolved from its cobamide coenzyme, was purified 35 -fold. The apoenzyme was stable for several days in the presence of ethanolamine, dithiothreitol, glycerol and $\mathrm{K}^{+}$ions.

Enzyme formation therefore requires both substrate and cobamide coenzyme to be present simultaneously as inducers.

\section{INTRODUCTION}

Ethanolamine ammonia-lyase (EC. 4.3.1.7), a cobamide coenzyme-dependent enzyme discovered in a strain of Clostridium (Bradbeer, I $965 a, b$ ), the mechanism of which has been extensively studied (Barker, 1972), has recently been found in Escherichia coli and Klebsiella aerogenes. These bacteria were capable of growth on glycerol with ethanolamine as the sole source of nitrogen only when vitamin $B_{12}$ was included in the medium. The vitamin promoted the assimilation of $\left[{ }^{14} \mathrm{C}\right]$ ethanolamine by growing cultures, which occurred even when an alternative nitrogen source was present, and ethanolamine induced formation of the ammonia-lyase enzyme (Blackwell, Scarlett \& Turner, 1976; Scarlett \& Turner, 1976).

Evidence is presented here that in $E$. coli, which is unable to synthesize vitamin $\mathbf{B}_{12}$ (Foster et al., 1964), the induction of ethanolamine ammonia-lyase requires both ethanolamine and vitamin $\mathbf{B}_{12}$, or their derivatives, to be present simultaneously.

\section{METHODS}

Organism, growth media and assays. Escherichia coli was grown and $\left[{ }^{14} \mathrm{C}\right]$ ethanolamine assimilation and ethanolamine ammonia-lyase activity were measured as previously described (Scarlett \& Turner, 1976). 


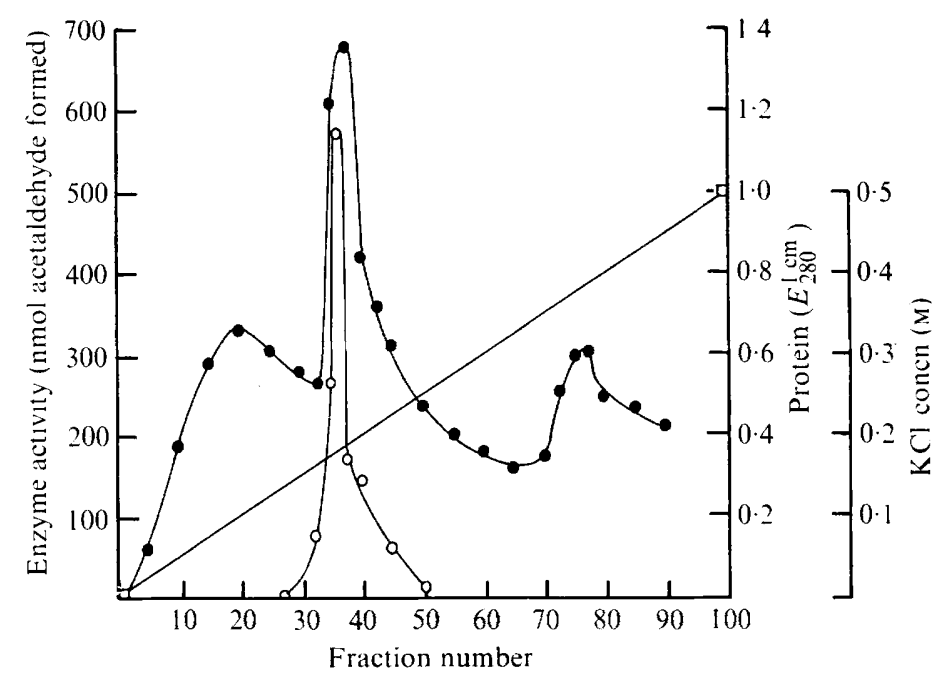

Fig. I. DEAE-cellulose chromatography of partially purified ethanolamine ammonia-lyase. An $\left(\mathrm{NH}_{4}\right)_{2} \mathrm{SO}_{4}$ fraction was prepared and chromatographed on DEAE-cellulose as described in Methods. The linear gradient in $\mathrm{KCl}$ concentration used to elute protein is indicated ( $\square$ ). Fractions of $5 \mathrm{ml}$ were collected. Protein was detected as $E_{280}(\Theta)$. Ethanolamine ammonia-lyase, $E_{670}(\bigcirc)$, was detected colorimetrically (Scarlett \& Turner, 1976).

Induction and repression of enzyme formation. Bacteria were grown routinely on media containing ( $\mathrm{g}$ per 1 distilled water): glycerol, 5 ; ethanolamine, $\mathrm{I}$; vitamin $\mathrm{B}_{12}$ (cyanocobalamin), $4 \times 10^{-5}$ (Scarlett \& Turner, 1976 ), as appropriate. Ethanolamine, vitamin $\mathbf{B}_{12}$ or both were added aseptically to cultures growing on the glycerol $/\left(\mathrm{NH}_{4}\right)_{2} \mathrm{SO}_{4} /$ mineral salts medium as indicated in the text. In kinetic experiments, inducer was added to cultures in the early exponential phase of growth $\left(E_{540}^{1 \mathrm{~cm}} 0.3\right.$ to 0.4$)$, and samples were removed for radioactivity, enzyme activity and cell density measurements as growth proceeded. In one or two experiments the inducer was added at different stages of growth $\left(E_{540}^{1 \mathrm{~cm}} 0.3\right.$ to I.0) and cultures were harvested for analysis towards the end of the exponential phase $\left(E_{540}^{\mathrm{I} \mathrm{cm}} \mathrm{I}^{\circ} 0\right)$. Chloramphenicol $\left(0.5 \mathrm{~g}^{-1}\right)$ was added to all culture samples before harvesting and analysis. The same procedures were used to follow repression of enzyme formation. All cultures were grown at $30^{\circ} \mathrm{C}$. Results are expressed as the differential rate of enzyme formation (or radioactivity incorporation) relative to growth, except where growth was inhibited, when a time scale is used.

Partial purification of ethanolamine ammonia-lyase apoenzyme. Crude cell-free extracts of bacteria grown on glycerol/ethanolamine/vitamin $\mathbf{B}_{12}$ medium, containing about $35 \mathrm{mg}$ protein $\mathrm{ml}^{-1}$, were prepared in $0.02 \mathrm{M}$-Tris/HCl, pH 7.5 (Scarlett \& Turner, 1976). Resolution of the enzyme from its cofactor was achieved by gentle stirring with activated charcoal [Sigma; $\mathrm{r} \mathrm{mg} \mathrm{(mg} \mathrm{protein)}{ }^{-1}$ ] for Io min at o to $4{ }^{\circ} \mathrm{C}$. The suspension was centrifuged (I0000 $\mathrm{g}$ for $20 \mathrm{~min}$ ) to remove the charcoal and the extract was diluted to $30 \mathrm{mg}$ protein $\mathrm{ml}^{-1}$. Solid $\left(\mathrm{NH}_{4}\right)_{2} \mathrm{SO}_{4}$ (low in heavy metals, for enzyme work; Fisons Scientific Apparatus) was gradually added to a slowly stirred sample ( $16.4 \mathrm{~g} / 100 \mathrm{ml}$ extract) at $0^{\circ} \mathrm{C}$ and equilibrated for $30 \mathrm{~min}$. Precipitated protein was removed by centrifuging ( $10000 \mathrm{~g}$ for $15 \mathrm{~min}$ ) and dissolved in $0.05 \mathrm{M}$-Tris/ $\mathrm{HCl}, \mathrm{pH} 7.5$, containing $20 \%(\mathrm{v} / \mathrm{v})$ glycerol, Io mM-ethanolamine, I mM-dithiothreitol and Io $\mathrm{mM}-\mathrm{KCl}$, to give a protein concentration of $20 \mathrm{mg} \mathrm{ml}^{-1}$. This fraction was dialysed against Ioo vol. of the same supplemented buffer mixture for 
Table I. Effect of ethanolamine analogues on ethanolamine ammonia-lyase activity

Escherichia coli was grown on glycerol/ethanolamine/vitamin $\mathbf{B}_{12}$ medium, cell-free extracts were prepared and ammonia-lyase activity was assayed colorimetrically as described by Scarlett \& Turner, 1976 . The specific activity was about $350 \mathrm{mmol}$ acetaldehyde formed $\mathrm{min}^{-1}$ (mg protein) ${ }^{-1}$. Inhibitory analogues were used at the same concentration as ethanolamine, $2 \mathrm{~mm}$.

$\begin{array}{lc}\text { Analogue } & \begin{array}{c}\text { Inhibition } \\ (\%)\end{array} \\ \text { I-Aminopropan-2-ol } & 58 \\ \text { I,3-Diaminopropan-2-ol } & 42 \\ \text { 3-Phenylserine } & 39 \\ \text { I-Bromopropan-2-ol } & 36 \\ \text { 2-Methylaminoethanol } & 33 \\ \text { 2-Bromoethanol } & 29 \\ \text { L-Threonine } & 27 \\ \text { I-Amino-3-diethylamino- } & \\ \text { propan-2-ol } & 26\end{array}$

$\begin{array}{lc}\text { Analogue } & \begin{array}{c}\text { Inhibition } \\ (\%)\end{array} \\ \text { D-Serine } & 26 \\ \text { Glycerol } & 25 \\ \text { Isoserine } & 24 \\ \text { 4-Amino-3-hydroxy- } & 23 \\ \text { butyrate } & \\ \text { 3-Aminopropan-I-ol } & 23 \\ \text { Malate } & 21 \\ \text { Lactate } & \text { I8 } \\ \text { I-Chloropropan-2-ol } & 8\end{array}$

$4 \mathrm{~h}$ at 0 to $4{ }^{\circ} \mathrm{C}$. Approximately $7 \mathrm{ml}$ extract, containing $20 \mathrm{mg}$ protein $\mathrm{ml}^{-1}$, was applied to a column $(30 \mathrm{~cm} \times 2 \mathrm{~cm}$ diam.) of Whatman DE52 DEAE-cellulose equilibrated with $0.05 \mathrm{M}-$ Tris $/ \mathrm{HCl}, \mathrm{pH} 7 \cdot 5$, containing $20 \%$ (v/v) glycerol and $4 \mathrm{~mm}$-dithiothreitol. The column was washed with approximately $100 \mathrm{ml}$ equilibration buffer and protein was eluted with an increasing concentration gradient of 0 to $0.5 \mathrm{M}-\mathrm{KCl}$ in the same buffer mixture containing ro mM-ethanolamine, over a total volume of $500 \mathrm{ml}$. Fractions $(5 \mathrm{ml})$ were collected and enzyme activity was detected by the standard colorimetric assay (Scarlett \& Turner, 1976). Specific activity measurements of the peak fractions (Fig. I) showed approximately 35 -fold purification overall, i.e. relative to crude extract, with at least $30 \%$ recovery. No activity was detected in eluate fractions other than in the region shown.

\section{RESULTS}

\section{Induced enzyme formation}

Measurement of ethanolamine ammonia-lyase activity in extracts of $E$. coli showed that ethanolamine and vitamin $\mathbf{B}_{12}$ were both required for enzyme induction; neither was effective by itself. The enzyme was induced when substrate and vitamin were added to cultures growing exponentially on glycerol $/\left(\mathrm{NH}_{4}\right)_{2} \mathrm{SO}_{4}$ medium and in that sense induction was gratuitous.

Previous results had shown that the vitamin $\mathbf{B}_{12}$-dependent ethanolamine deamination system in $E$. coli was specific in that none of a number of substrate analogues tested was capable of acting as an alternative source of nitrogen for growth (Scarlett \& Turner, 1976). When tested as inhibitors of ethanolamine ammonia-lyase activity in cell-free extracts, DL-I-aminopropan-2-ol and DL-I,3-diaminopropan-2-ol were the most inhibitory of these analogues (Table I). Both compounds inhibited competitively. They also inhibited the growth of $E$. coli on glycerol/ethanolamine/vitamin $\mathrm{B}_{12}$ but not on glycerol $/\left(\mathrm{NH}_{4}\right)_{2} \mathrm{SO}_{4}$ medium. The degree of growth inhibition depended on the concentration of inhibitor, a prolonged lag occurring when analogues were used at 15 to $20 \mathrm{mM}$ with ethanolamine at I6.7 mM. None of the compounds listed in Table $I$ induced ammonia-lyase formation when added as a supplement ( $\mathrm{g} \mathrm{l}^{-1}$ ) to glycerol/ $\left(\mathrm{NH}_{4}\right)_{2} \mathrm{SO}_{4} /$ vitamin $\mathrm{B}_{12}$ medium. I-Aminopropan-2-ol, in addition to inhibiting ammonia-lyase activity, prevented ethanolamine- 


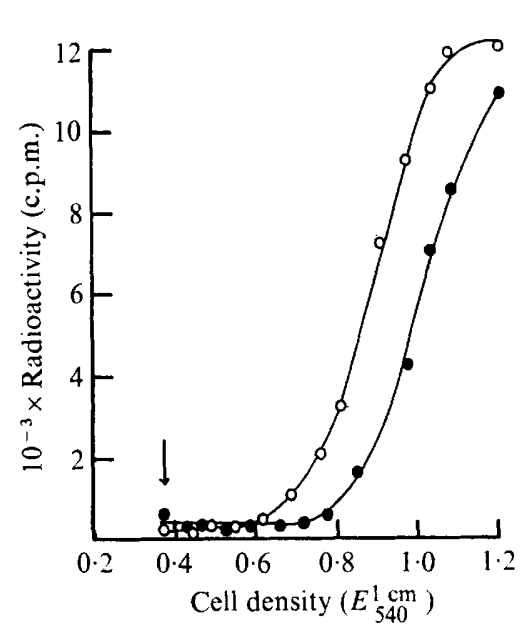

Fig. 2

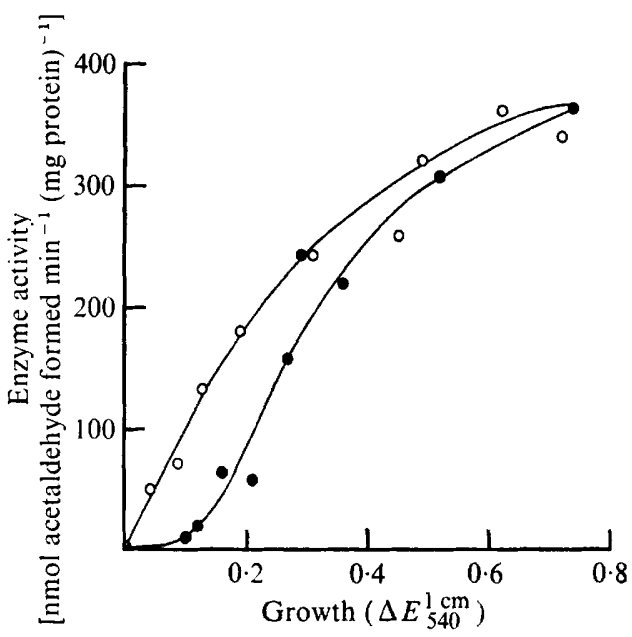

Fig. 3

Fig. 2. Assimilation of $\left[{ }^{14} \mathrm{C}\right]$ ethanolamine by $E$. coli following the addition of ethanolamine or vitamin $\mathrm{B}_{12}$ to cultures containing the complementary inducer. Escherichia coli was inoculated into glycerol/ $\left(\mathrm{NH}_{4}\right)_{2} \mathrm{SO}_{4}$ medium containing either ethanolamine or vitamin $\mathrm{B}_{12}$ at the start of growth. The complementary inducers were added at the time indicated by the arrow. As growth proceeded, samples were removed as indicated for measurements of the radioactivity assimilated by the bacteria (Scarlett \& Turner, 1976). The inducer triggering enzyme synthesis was ethanolamine $(O)$ or vitamin $\mathrm{B}_{12}(\mathbf{O})$.

Fig. 3. Differential rate of ammonia-lyase synthesis induced by the addition of ethanolamine or vitamin $\mathbf{B}_{12}$ during growth. The procedure was similar to that described for Fig. 2 except that enzyme activity was measured in extracts of the bacteria sampled at the stage of growth shown. Enzyme formation was induced by the addition of ethanolamine $(O)$ or vitamin $\mathbf{B}_{12}(\mathcal{O})$. Bacterial growth is expressed as the increase in cell density between the addition of inducer and harvesting at the end of the exponential phase (see Methods).

induced synthesis of the enzyme when added as a supplement ( g $\left.^{-1}\right)$ to ethanolaminecontaining medium.

The time course of ethanolamine metabolism in $E$. coli induced by adding substrate and vitamin $\mathbf{B}_{12}$ to growing cultures was studied in two ways. A sensitive radiotracer method was used to follow the incorporation of $\left[{ }^{14} \mathrm{C}\right]$ ethanolamine into cells after addition of ethanolamine to cultures growing on glycerol $/\left(\mathrm{NH}_{4}\right)_{2} \mathrm{SO}_{4} /$ vitamin $\mathrm{B}_{12}$ medium, or after addition of vitamin $B_{12}$ to cultures growing in the presence of ethanolamine. When vitamin $\mathbf{B}_{12}$ was already present in the medium, addition of ethanolamine led to its metabolism after a short lag period whereas when the vitamin was added to media already containing ethanolamine the lag period was significantly longer (Fig. 2). When the induction of ammonia lyase formation was followed directly, the differential rate of formation was again more rapid when ethanolamine was added to cultures containing vitamin $B_{12}$ rather than the reverse (Fig. 3).

\section{Repression of enzyme formation}

When ammonia-lyase formation was induced by growing $E$. coli on carbon sources other than glycerol plus $\left(\mathrm{NH}_{4}\right)_{2} \mathrm{SO}_{4}$, with ethanolamine and-vitamin $\mathrm{B}_{12}$, many of the carbon sources appeared to act as repressors. Glucose and acetate were particularly effective (see Table $2 a$ ). Similar results were obtained by adding glucose or acetate as supplements to the standard glycerol $/\left(\mathrm{NH}_{4}\right)_{2} \mathrm{SO}_{4}$ medium before inducing enzyme formation (Table $2 b$ ). The 
Table 2. Effect of carbon source for growth on ethanolamine ammonia-lyase formation

(a) Escherichia coli was grown on media containing ethanolamine, vitamin $\mathbf{B}_{\mathbf{1 2}}$, mineral salts, and different carbon sources instead of glycerol (see Methods). Induced enzyme formation was measured by assaying ammonia-lyase activity in extracts of bacteria harvested in the exponential phase. (b) Ammonia-lyase formation was induced by adding ethanolamine and vitamin $\mathrm{B}_{12}$ to glycerol/ $\left(\mathrm{NH}_{4}\right)_{2} \mathrm{SO}_{4}$ media supplemented with either glucose or acetate.

(a) Major carbon source $\left(5 \mathrm{~g}^{-1}\right)$

Glycerol

Succinate

L-Alanine

L-Aspartate

Maltose

Pyruvate

Fumarate

Malate

Lactate

Lactose

Glucose

Acetate (b) Carbon source supplementing glycerol (both $5 \mathrm{~g}^{-1}$ )

$\begin{array}{lr}\text { None } & 100 \\ \text { Acetate } & 59 \\ \text { Glucose } & 33\end{array}$
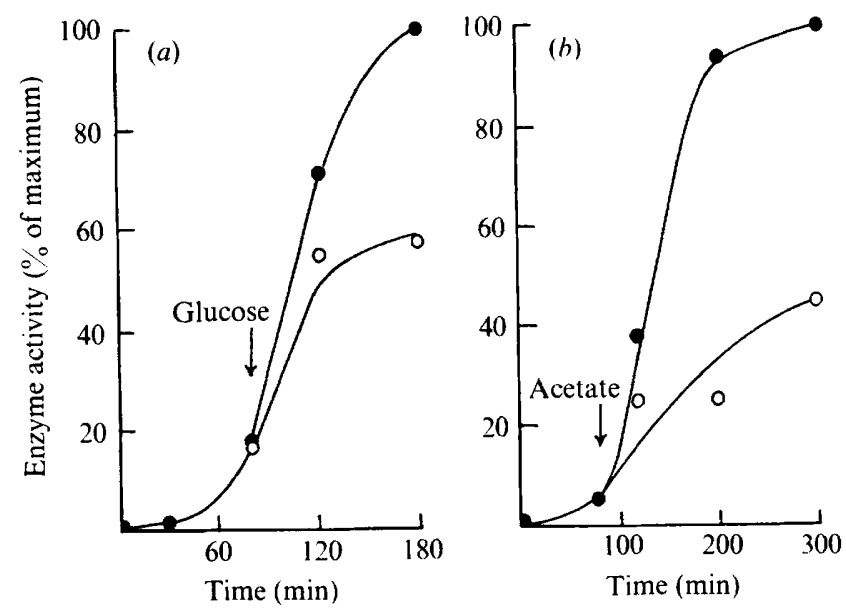

Fig. 4. Repression of ammonia-lyase formation by $(a)$ glucose and $(b)$ acetate. Cultures were grown on glycerol/ $\left(\mathrm{NH}_{4}\right)_{2} \mathrm{SO}_{4} /$ vitamin $\mathrm{B}_{12}$ medium. When the mid-exponential phase of growth was reached $\left(E_{540}^{\mathrm{Icm}} 0^{\circ} 4\right)$, ethanolamine was added to induce enzyme formation and the culture was divided. At the times indicated by the arrows, glucose or acetate $(O)$ was added $\left(5 \mathrm{gl}^{-1}\right)$, no addition (๑) being made to the controls. Samples of bacteria were removed for assays of enzyme activity at the times shown. Maximum enzyme activities observed were 247 and $186 \mathrm{nmol}$ acetaldehyde formed $\mathrm{min}^{-1}(\mathrm{mg} \text { protein })^{-1}$ in the glucose and acetate experiments respectively.

differential rates of enzyme formation during growth on glycerol in the presence or absence of glucose and acetate are shown in Fig. 4.

\section{Effect of chloramphenicol on enzyme formation}

Chloramphenicol prevented enzyme formation. Bacteria were grown on glycerol/ $\left(\mathrm{NH}_{4}\right)_{2} \mathrm{SO}_{4}$ medium supplemented with ethanolamine. When the mid-exponential phase of growth had been reached, vitamin $\mathbf{B}_{12}$ was added to induce enzyme formation and the 
culture was divided into two portions. After a suitable time interval, chloramphenicol was added to one portion, the other acting as a control. Samples of cells were removed at appropriate times and the enzyme activity in cell-free extracts was measured. The formation of enzyme was completely prevented by chloramphenicol at concentrations above $0.2 \mathrm{~g}^{\mathbf{1}} \mathbf{1}$.

\section{Stability of apoenzyme preparations}

Ethanolamine might induce the formation of the ammonia-lyase in the absence of vitamin $B_{12}$ but give an apoenzyme which was unstable without the coenzyme. To investigate this possibility, the enzyme in crude extracts was resolved by charcoal treatment, followed by fractionation with $\left(\mathrm{NH}_{4}\right)_{2} \mathrm{SO}_{4}$ and DEAE-cellulose chromatography (see Methods). This purified the enzyme approximately 35 -fold and gave at least $30 \%$ recovery. As purification progressed, the enzyme became increasingly labile in the absence of ethanolamine and dithiothreitol, particularly at low protein concentrations. Glycerol and $\mathbf{K}^{+}$ions also protected against activity loss. Storage of the purified apoenzyme for 6 days at $4{ }^{\circ} \mathrm{C}$ in $0.05 \mathrm{M}$-Tris/ $\mathrm{HCl}$ buffer, $\mathrm{pH} \mathrm{7.5}$, containing Io mM-ethanolamine, $4 \mathrm{~mm}$-dithiothreitol, $20 \%(\mathrm{v} / \mathrm{v})$ glycerol and $0.10 \mathrm{M}-\mathrm{KCl}$, resulted in the loss of only $20 \%$ of the original activity. With the exception of ethanolamine, activity-stabilizing factors restored some of the activity lost by enzyme preparations stored or dialysed in their absence.

\section{DISCUSSION}

Synthesis of the ethanolamine ammonia-lyase of $E$. coli only in the presence of both its substrate and the vitamin precursor of its coenzyme was unexpected. The only other cobamide-requiring enzyme known in $E$. coli, the tetrahydropteroylglutamate methyltransferase (EC. 2.I.I.I3) catalysing the conversion of homocysteine to methionine, is synthesized in the absence of vitamin $B_{12}$ (Takeyama, Hatch \& Buchanan, I96I). The requirements for ammonia-lyase synthesis would appear to be more advantageous to the bacterium.

Concerted or 'multivalent' induction of the synthesis of any enzyme does not appear to have been described previously but must be considered in the case of ethanolamine ammonia-lyase. Results obtained with the purified apoenzyme argue against the possibility that vitamin $B_{12}$ was needed to stabilize the enzyme by providing the necessary coenzyme, although a role in enzyme assembly cannot be excluded. The delay in ammonia-lyase formation observed when vitamin $\mathbf{B}_{12}$ was added to cultures growing with ethanolamine, rather than the reverse, may represent the time required to convert the vitamin to its coenzyme form. Alternatively, the delay may be due to different rates for the transport of ethanolamine and vitamin $\mathbf{B}_{12}$ into the cell. A time lag for the effect of vitamin $\mathbf{B}_{12}$ on the metabolism of $E$. coli has been observed previously (Oginsky et al., I95I) and a transport system specific for the vitamin has been demonstrated in this bacterium (Di Girolamo \& Bradbeer, 197I; Taylor, Norrell \& Hanna, 1972). A third possibility is that vitamin $\mathrm{B}_{\mathbf{1 2}}$ is required for the transport of ethanolamine into $E$. coli, but this seems less likely.

In the absence of evidence to the contrary, we suggest that both substrate and cobamide coenzyme are needed in concert as inducers of ethanolamine ammonia-lyase formation in E. coli. Little is known of the control of synthesis of the enzyme in the strain of Clostridium studied (Bradbeer, $1965 a$ ) and $E$. coli is an appropriate bacterium for further investigations.

Part of this work was carried out with the aid of a grant from the Medical Research Council. The interest and support of Professor T. W. Goodwin, F.R.S., is gratefully acknowledged. 


\section{REFERENCES}

BARKer, H. A. (1972). Corrinoid-dependent enzymic reactions. Annual Review of Biochemistry 4I, 55-90.

Blackwell, C. M., Scarlett, F. A. \& Turner, J. M. (1976). Ethanolamine catabolism by bacteria, including Escherichia coli. Biochemical Society Transactions 4, 495-497.

BradBeER, C. $(1965 a)$. The clostridial fermentations of choline and ethanolamine. I. Preparation and properties of cell-free extracts. Journal of Biological Chemistry 240, 4669-4674.

Bradbeer, C. $(1965 b)$. The clostridial fermentations of choline and ethanolamine. II. Requirement for a cobamide coenzyme by an ethanolamine deaminase. Journal of Biological Chemistry 240, 4675-468I.

Di Girolamo, P. M. \& Bradbeer, C. (I97I). Transport of vitamin $\mathrm{B}_{12}$ in Escherichia coli. Journal of Bacteriology ro6, 745-750.

Foster, M. A., Tejerina, G., Guest, J. R. \& Woods, D. D. (I964). Two enzymic mechanisms for the methylation of homocysteine by extracts of Escherichia coli. Biochemical Journal 92, 476-488.

Oginsky, E. L., Smith, P. H., Tonhazy, N. E., Umbreit, W. W., Lichstein, H. C. \& Carson, S. F. (I95I). The influence of vitamin $\mathrm{B}_{12}$ on oxidation by a mutant strain of Escherichia coli. Journal of Bacteriology 6r, $58 \mathrm{I}-590$.

SCARlett, F. A. \& Turner, J. M. (I976). Microbial metabolism of amino alcohols. Ethanolamine catabolism mediated by coenzyme $\mathrm{B}_{12}$-dependent ethanolamine ammonia-lyase in Escherichia coli and Klebsiella aerogenes. Journal of General Microbiology 95, 173-1 76.

Takeyama, S., Hatch, F. T. \& Buchanan, J. M. (I96I). Enzymatic synthesis of the methyl group of methionine. II. Involvement of vitamin $\mathrm{B}_{12}$. Journal of Biological Chemistry 236, I I02-I 108.

TAYlor, R. T., Norrell, S. A. \& Hanna, M. L. (I972). Uptake of cyanocobalamin by Escherichia coli. Some characteristics and evidence for a binding protein. Archives of Biochemistry and Biophysics I48, 366-38x. 